\title{
KAITAN LATAR BELAKANG PENDIDIKAN GURU TER- HADAP PEMANFAATAN CANDI KOTES SEBAGAI SUMBER BELAJAR
}

\author{
Mia Juwita Kaningtyas \\ Pascasarjana Pendidikan Sejarah Universitas Negeri Malang
}

\begin{abstract}
Abstrak. Penelitian ini menjelaskan tentang kaitan antara latar belakang pendidikan guru terhadap pemanfaatan candi Kotes sebagai sumber belajar. Candi Kotes merupakan salah satu sumber belajar sejarah berbasis lingkungan yang dapat digunakan guru guna memaksimalkan pembelajaran sejarah. Namun, pada kenyataannya candi Kotes kurang dimanfaatkan oleh guru sebagai sumber belajar sejarah. Salah satu faktor penyebab minimnya pemanfaatan candi Kotes sebagai sumber belajar sejarah adalah pengetahuan guru. Pengetahuan guru terbentuk melalui pengalaman dan pendidikan. Mayoritas latar belakang pendidikan guru bukan berasal dari pendidikan sejarah, sehingga guru kurang memahami sejarah candi Kotes. Hal tersebut berdampak terhadap ketidakmampuan guru dalam memanfaatkan candi Kotes sebagai sumber belajar, sehingga salah satu unsur pembelajaran sejarah yaitu memanfaatkan sumber belajar semaksimal mungkin kurang terpenuhi.
\end{abstract}

Kata-kata kunci : Latar Belakang Pendidikan, Candi Kotes, Sumber Belajar

\begin{abstract}
This study is concern on the correlation between teacher education background and the use of Kotes Temple as the learning resource. Candi Kotes is one of a learning resource based on environment that can used by teacher to improve the learning of history. In fact, the use of Kotes Temple as history learning resource is low. One of the causal factor is teacher knowledge. Teacher knowledge is built from an experience and an education background. Most of teachers have no history education background. Consequently, teachers have no knowledge about Kotes Temple. It is also influenced teacher's ability to use Kotes Temple as historical learning source, therefore the using of learning source might not be filled.
\end{abstract}

Keywords: history education background, Kotes Temple, learning source

Kecamatan Gandusari merupakan salah satu wilayah di kabupaten Blitar yang kaya akan peninggalan-peninggalan sejarah berupa candi sebagai salah satu bentuk benda cagar budaya. Keberadaan bendabenda cagar budaya tersebut banyak tersebar di kecamatan Gandusari. Terdapat empat candi yang tersebar di wilayah kecamatan Gandusari yaitu candi Kotes, Wringin Bajang, Rambut Monte dan Serah Kencong. Selain itu juga terdapat beberapa situs yang tersebar di kecamatan Gandusari seperti situs Sukosewu yang terletak tidak jauh dari candi Kotes, Batu Kasur yang terletak di desa Butun Kecamatan Gandusari, dan situs
Sumberagung yang terletak di desa Sumberagung Kecamatan Gandusari.

Benda-benda peninggalan sejarah yang tersebar di kecamatan Gandusari tersebut berpotensi sebagai tempat wisata sejarah sekaligus sumber belajar sejarah bagi pelajar maupun umum, salah satunya adalah candi Kotes. Candi Kotes merupakan candi terbesar di kecamatan Gandusari yang masih sangat terawat dengan baik walaupun kondisi bangunan candi sudah tidak utuh. Disamping menjadi tempat rekreasi dan pelaksanaan ritual keagamaan, candi Kotes juga memiliki potensi sebagai sumber belajar sejarah bagi pelajar maupun masyarakat 
umum di wilayah kecamatan Gandusari maupun luar wilayah kecamatan Gandusari. Keberadaan candi Kotes berpotensi untuk memperdalam ilmu-ilmu sosial dan kemanusiaan serta dapat menumbuhkan kesadaran perserta didik untuk memiliki kecintaan terhadap alam sehingga dapat berpartisipasi dalam memelihara dan melestarikan alam.

Menurut Macbeat dan Mortimore, sumber belajar yang baik adalah sumber belajar yang mudah diperoleh, baik karena dekat jarak antara tempat sumber belajar dengan pemakai tetapi juga jumlah sumber belajar cukup banyak (Macbeath, 2001:85). Dalam bidang pembelajaran, pemanfaatan candi Kotes sebagai sumber belajar mempunyai keuntungan praktis ekonomis. Keuntungan praktis karena mudah diperoleh, sedangkan keuntungan ekonomis karena murah dan dapat dijangkau oleh seluruh siswa. Penggunaan sumber belajar juga semakin maksimal apabila bahan media tersebut diambil atau terdapat di lingkungan setempat (Hill, 1956:80).

Pemanfaatan candi Kotes memberikan peluang kepada para siswa untuk mengembangkan pengetahuan cinta akan lingkungan serta kesadaran sejarah pada lingkungan tempat tinggal mereka. Hal tersebut sesuai dengan salah satu tujuan pembelajaran IPS yang diungkapkan oleh Suhanaji dan Waspodo (2007: 7) yaitu guna memberikan pengertian dan penghargaan terhadap nilai-nilai budaya dan tradisi yang diwariskan oleh bangsanya.

Berkaitan dengan lingkungan sebagai sumber belajar Depoter dan Herracki (2001:81) menyatakan bahwa semakin berinteraksi dengan lingkungan, maka siswa akan semakin mahir mengatasi situasisituasi yang menantang dan semakin mudah dalam mempelajari suatu informasi yang baru. Pemanfaatan candi Kotes sebagai sumber belajar sejarah diharapkan dapat menjadikan pembelajaran sejarah pada mata pelajaran IPS tidak hanya bersifat verbalitas tetapi lebih mengarah pada tujuan yang bersifat lebih afektif.

Artinya, setelah memperoleh pengalaman belajar secara langsung dan berinteraksi dengan peninggalan sejarah, peserta didik memiliki sikap dan mampu mengambil hikmah dari keberadaan benda cagar budaya, baik dari aspek waktu, semangat, teknologi maupun proses pembuatannya. Dari segi teknologi pembuatannya misalnya, para peserta didik akan dapat membandingkan kemampuan sumber daya manusia dan kemajuan teknologi pada masa lalu dengan masa sekarang.

Pada kenyataannya keberadaan candi Kotes di kecamatan Gandusari tidak dimanfaatkan secara maksimal sebagai sumber belajar sejarah pada mata pelajaran IPS bagi kalangan pelajar di Gandusari. Candi Kotes jarang dimanfaatkan sebagai sumber belajar sejarah bagi sekolah-sekolah yang ada di sekitarnya. Padahal candi Kotes merupakan contoh nyata bagi siswa untuk belajar secara lebih dalam guna mengenal karakter bangsa Indonesia secara langsung selain menggunakan sumber belajar sejarah dalam bentuk teks.

Rata-rata hanya sekitar $40 \quad \%$ pengunjung candi Kotes berasal dari kalangan pelajar di lingkungan kecamatan Gandusari, sedangkan $60 \%$ berasal dari masyarakat umum dengan berbagai kepentingan baik rekreasi maupun ritual keagamaan. Pengunjung candi Kotes per harinya tergolong tidak tentu, bahkan seringkali tidak ada pengunjung sama sekali yang berkunjung ke candi Kotes padahal untuk memasuki area candi Kotes tidak dipungut biaya sama sekali.

Menurut Percival dan Elington bahwa dalam pembelajaran dengan model konvensional, dari sekian banyak sumber belajar yang ada, ternyata hanya buku teks yang merupakan sumber belajar yang dimanfaatkan selain tenaga pengajar itu 
sendiri. Sedangkan mengenai sumber belajar yang beraneka ragam pada umumnya belum dimanfaatkan secara maksimal (Elington, 1993:71-72). Mayoritas guru pada sekolah-sekolah di sekitar candi Kotes menerapkan pembelajaran secara konvensional, yaitu dengan menggunakan sumber belajar sejarah berupa buku teks. Dari delapan guru sejarah pada mata pelajaran IPS yang menjadi informan, hanya 2 orang guru saja yang pernah menggunakan candi Kotes sebagai sumber belajar sejarah.

Penggunaan bahan ajar dan buku teks dalam pembelajaran sangat dominan bila dibandingkan dengan sumber belajar seperti perpustakaan, laboratorium, studi lapangan, slide, internet, komputer dan lainnya (Abdullah, 2012:2). Pembelajaran sejarah pada mata pelajaran IPS pada sekolah-sekolah di sekitar candi Kotes masih cenderung konvensional karena berbasis hanya pada penggunaan buku teks dan LKS siswa. Sehingga pennggunaan sumber belajar sejarah pada mata pelajaran IPS masih belum maksimal.

Sumber belajar yang ada pada lingkungan sekitar hendaknya dapat dimanfaatkan sebaik-baiknya dalam proses pembelajaran (Morrison, 2004:23-26). Sedangkan pada kenyataannya mayoritas guru kurang memanfaatkan lingkungan sekitar sebagai sumber belajar sejarah. Sehingga dimungkinkan pembelajaran sejarah menjadi kurang maksimal mengingat kurang terpenuhinya salah satu aspek dalam pembelajaran sejarah yaitu pemanfaatan sumber belajar seluas mungkin.

Pemanfaatan lingkungan sebagai sumber belajar sangat tergantung pada kemauan dan kemampuan pengajarnya (Miarso, 2004:177-178). Terdapat dua point penting yang menjadi latar belakang guru untuk memanfaatkan candi Kotes sebagai sumber belajar sejarah, yaitu kemauan dan kemampuan guru. Fokus kajian ini adalah untuk mengetahui kemampuan guru dalam memanfaatkan candi Kotes sebagai sumber belajar sejarah. Kemampuan guru berkaitan erat dengan pengetahuan yang dimiliki guru. Pengetahuan guru berkaitan erat dengan latar belakang pendidikan guru. Sehingga dimungkinkan muncul keterkaitan yang kuat antara keduanya.

Penelitian mengenai sumber belajar sejarah juga pernah dilakukan oleh Neneng Dewi Setiawati (2013). Hasil yang didapat dari penelitian tersebut adalah salah satu faktor yang melatar belakangi minimnya pemanfaatan sumber belajar dengan menggunakan benda cagar budaya sebagai sumber belajar adalah kendala biaya.

\section{METODE PENELITIAN}

Penelitian ini menggunakan pendekatan kualitatif dengan jenis penelitian deskriptif. Penelitian ini menggunakan teknik wawancara secara mendalam terhadap guru sejarah pada mata pelajaran IPS di enam sekolah yang berada pada radius 5 $\mathrm{km}$ dari candi Kotes. Guru yang menjadi informan adalah delapan orang guru IPS untuk Kelas V SD dan kelas VII SMP. Guru IPS kelas V SD dan kelas VII SMP dipilih sebagai informan dikarenakan materi sejarah dengan tema peninggalan-peninggalan kerajaan Hindu di Indonesia diajarkan pada kelas-kelas tersebut. Data pada penelitian ini terdiri dari hasil wawancara secara mendalam terhadap delapan orang guru sebagai informan meliputi latar belakang pendidikan guru, pengetahuan guru dan kaitannya dengan pemanfaatan candi Kotes sebagai sumber belajar sejarah. Berikut daftar rekapitulasi informan: 
Tabel 1. Rekapitulasi jumlah guru IPS di sekolah-sekolah baik SD maupun SMP yang ada di sekitar candi Kotes.

\begin{tabular}{|c|c|c|c|}
\hline No. & Nama Sekolah & Jumlah Guru IPS & Ket \\
\hline 1 & SDN Kotes 01 & 1 orang & \\
\hline 2 & SDN Sukosewu 01 & 1 orang & \\
\hline 3 & SDN Tambakan 01 & 1 orang & \\
\hline 4 & SDN Sukosewu 04 & 1 orang & \\
\hline 5 & SMP PGRI Gandusari & 1 orang & \\
\hline \multirow[t]{2}{*}{6} & SMP Negeri 2 Gandusari & 3 orang & \\
\hline & Total Informan & 8 orang & \\
\hline
\end{tabular}

Prosedur analisis yang digunakan dalam apa yang dikembangkan oleh Miles \& penelitian ini sebagaimana merujuk dari Humberman sebagai berikut:

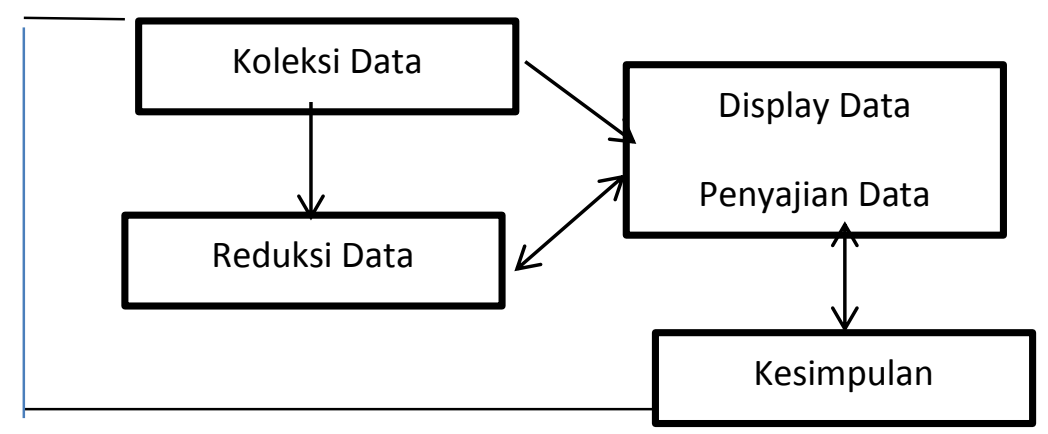

Bagan 1. Komponen dalam Analisis Data (Model Interaktif) (Sumber : Miles dalam Sugiono, 2011)

\section{HASIL PENELITIAN}

\section{Latar Belakang Pendidikan Guru}

Latar belakang pendidikan guru yang menjadi informan tergolong cukup baik. Berikut rekapitulasi latar belakang pendidikan guru IPS yang menjadi informan, baik dari jenjang SD maupun SMP

Tabel 2. Rekapitulasi Latar Belakang Pendidikan Guru IPS pada SD dan SMP di Sekitar Candi Kotes

\begin{tabular}{|c|c|c|c|c|c|}
\hline \multirow[t]{2}{*}{ No. } & \multirow[t]{2}{*}{ Nama Sekolah } & \multirow[t]{2}{*}{ Nama Guru } & $\begin{array}{ll}\text { Latar } & \text { Belakang }\end{array}$ & Jenjang & Tersertifikasi \\
\hline & & & \multicolumn{3}{|l|}{ Pendidikan } \\
\hline 1 & SMP PGRI Gandusari & Hj. Ninik Wigiati, S.Pd & IPS-Ekonomi & S1 & Sudah \\
\hline \multirow[t]{3}{*}{2} & SMPN 2 Gandusari & Drs. Abdul Manaf & IPS-Sejarah & S1 & Sudah \\
\hline & & Maksum, S.Pd & IPS-Ekonomi & S1 & Sudah \\
\hline & & Sriani, M.Pd & IPS-Ekonomi & S2 & Belum \\
\hline 3 & SDN Tambakan I & Joko Suseno, S.Pd & PGSD & S1 & Sudah \\
\hline 4 & SDN Kotes I & Hariyati, S.PD,SD & PGSD & $\mathrm{S} 1$ & Sudah \\
\hline 5 & SDN Sukosewu I & Imam Taptoyani, A.MA & PGSD & D2 & Belum \\
\hline 6 & SDN Sukosewu 4 & Sunarto, S.Pd.SD & PGSD & S1 & Sudah \\
\hline
\end{tabular}


Tabel 4. menjelaskan bahwa mayoritas guru merupakan lulusan sarjana S1 pada bidang pendidikan. Hanya satu orang guru saja yang tidak berlatar belakang S1. Latar belakang pendidikan guru yang menjadi informan cukup beragam. Kebanyakan guru yang menjadi informan tidak memiliki latar belakang pendidikan sejarah. Hanya ada satu orang guru saja yang memiliki latar belakang pendidikan sejarah.

Ketidak sesuaian latar belakang pendidikan guru dengan mata pelajaran yang diajarkan merupakan faktor negatif terhadap pemanfaatan candi Kotes sebagai sumber belajar sejarah pada mata pelajaran IPS. Hal tersebut akan berdampak pada kurangnya pengetahuan guru mengenai materi sejarah candi Kotes. Kurangnya pengetahuan guru mengenai sejarah candi Kotes akan berdampak pada tindakan guru yaitu dengan tidak memanfaatkan candi Kotes sebagai sumber belajar sejarah pada mata pelajaran IPS.

Apabila guru tidak memanfaatkan candi Kotes sebagai sumber belajar sejarah maka hal tersebut berarti guru tidak memanfaatkan sumber belajar yang ada di lingkungan sekolah. Tindakan tersebut tidak sesuai dengan salah satu unsur pembelajaran IPS, yaitu memanfaatkan segala sumber belajar yang ada di lingkungan sekitar. Hal tersebut dimungkinkan akan membuat tujuan pembelajaran sejarah pada mata pelajaran IPS tidak akan tercapai dengan maksimal.

\section{Pengetahuan Guru Mengenai Sejarah candi Kotes}

Guru dikategorikan memiliki pengetahuan yang baik mengenai sejarah candi Kotes apabila guru mampu menjelaskan mengenai sejarah candi Kotes meliputi kapan dibangunnya candi Kotes, siapakah yang membangun candi Kotes dan apa tujuan dibangunnya candi Kotes. Sedangkan guru dikategorikan kurang memiliki pengetahuan mengenai sejarah candi Kotes apabila guru tidak mampu menjelaskan sejarah candi Kotes meliputi kapan dibangunnya candi Kotes, siapakah yang membangun candi Kotes dan apa tujuan dibangunnya candi Kotes.

Pengetahuan guru-guru IPS pada sekolah-sekolah di sekitar candi Kotes terhadap sejarah candi Kotes tergolong kurang. Pengetahuan guru terhadap sejarah candi Kotes dapat dipaparkan melalui tabel berikut :

Tabel 3. Rekapitulasi Pengetahuan Guru Terhadap Sejarah Candi Kotes

\begin{tabular}{|c|c|c|c|c|}
\hline No. & Nama Sekolah & Nama Guru & $\begin{array}{l}\text { Pengetahuan ten- } \\
\text { tang sejarah candi } \\
\text { Kotes } \\
\text { (ya/tidak) }\end{array}$ & Ket \\
\hline 1 & SMP PGRI Gandusari & Hj. Ninik Wigiati, S.Pd & Tidak & $\begin{array}{l}\text { Tidak berlatar belakang pend. Sejarah } \\
\text { Kurang Referensi }\end{array}$ \\
\hline \multirow[t]{2}{*}{2} & SMPN 2 Gandusari & $\begin{array}{l}\text { Drs. Abdul Manaf } \\
\text { Maksum, S.Pd }\end{array}$ & $\begin{array}{l}\text { Tidak } \\
\text { Tidak }\end{array}$ & $\begin{array}{l}\text { Kurang Referensi } \\
\text { Tidak berlatar belakang pend. Sejarah } \\
\text { Kurang Referensi }\end{array}$ \\
\hline & & Sriani, M.Pd & Tidak & $\begin{array}{l}\text { Tidak berlatar belakang pend. Sejarah } \\
\text { Kurang Referensi }\end{array}$ \\
\hline 3 & SDN Tambakan I & Joko Suseno, S.Pd & Tidak & $\begin{array}{l}\text { Tidak berlatar belakang pend. Sejarah } \\
\text { Kurang Referensi }\end{array}$ \\
\hline 4 & SDN Kotes I & Hariyati, S.PD,SD & Tidak & $\begin{array}{l}\text { Tidak berlatar belakang pend. Sejarah } \\
\text { Kurang Referensi }\end{array}$ \\
\hline 5 & SDN Sukosewu I & Imam Taptoyani, A.MA & Tidak & $\begin{array}{l}\text { Tidak berlatar belakang pend. Sejarah } \\
\text { Kurang Referensi }\end{array}$ \\
\hline
\end{tabular}




\begin{tabular}{|c|c|c|c|c|}
\hline 6 & SDN Sukosewu 4 & $\begin{array}{l}\text { Sunarto, S.Pd.SD } \\
\end{array}$ & Tidak & $\begin{array}{l}\text { Tidak berlatar belakang pend. Sejarah } \\
\text { Kurang Referensi }\end{array}$ \\
\hline
\end{tabular}

Tabel 3. diatas menunjukkan bahwa pengetahuan guru mengenai sejarah candi Kotes tergolong sangat kurang. Ketidak tahuan guru mengenai sejarah candi Kotes disebabkan latar belakang pendidikan guru dan minimnya ketersediaan referensi. Guru IPS yang menjadi informan mayoritas memiliki latar belakang non-sejarah (Ekonomi dan PGSD), hanya satu orang guru yang memiliki latar belakang pendidikan sejarah. Hal tersebut berdampak pada kurangnya pengetahuan guru mengenai sejarah candi Kotes. Disamping itu guru tidak memiliki referensi yang cukup berkaitan dengan sejarah candi Kotes. Sehingga guru sulit untuk mempelajari bagaimana sejarah candi Kotes tersebut.

\section{Pemanfaatan candi Kotes sebagai Sumber Belajar}

Pemanfaatan candi Kotes sebagai sumber belajar sejarah oleh

Tabel 4. Rekapitulasi Pemanfaatan Candi Kotes sebagai Sumber Belajar Sejarah
Kurangnya pengetahuan guru
mengenai sejarah candi Kotes merupakan faktor internal guru yang bersifat negatif. Karena guru yang menjadi informan tidak mengetahui sejarah candi Kotes. Dengan demikian guru tidak mampu memanfaatkan candi Kotes sebagai sumber belajar sejarah pada mata pelajaran IPS. Hal tersebut akan berdampak terhadap minimnya pemanfaatan candi Kotes sebagai sumber belajar sejarah. Minimnya pemanfaatan candi Kotes dimungkinkan akan berdampak terhadap kurang maksimalnya pembelajaran sejarah pada mata pelajaran IPS karena tidak memanfaatkan sumber-sumber belajar sejarah yang ada pada lingkungan sekitar.

guru cenderung kurang. Hal tersebut dapat dilihat pada tabel di bawah ini :

\begin{tabular}{|c|c|c|c|c|}
\hline No. & Nama Sekolah & Nama Guru & $\begin{array}{l}\text { Pemanfaatan } \\
\text { candi Kotes se- } \\
\text { bagai sumber } \\
\text { belajar }\end{array}$ & Alasan \\
\hline 1 & $\begin{array}{ll}\text { SMP } & \text { PGRI } \\
\text { Gandusari } & \end{array}$ & Hj. Ninik Wigiati, S.Pd & Tidak & $\begin{array}{l}\text { Kesibukan } \\
\text { Tidak memahami materi candi Kotes }\end{array}$ \\
\hline 2 & SMPN 2 Gandusari & Drs. Abdul Manaf & Tidak & $\begin{array}{l}\text { Akomodasi } \\
\text { Tidak memahami materi candi Kotes }\end{array}$ \\
\hline & & $\begin{array}{l}\text { Maksum, S.Pd } \\
\text { Sriani, M.Pd }\end{array}$ & $\begin{array}{l}\text { Tidak } \\
\text { Tidak }\end{array}$ & $\begin{array}{l}\text { Tidak memahami materi candi Kotes } \\
\text { Tidak memahami materi candi Kotes } \\
\text { Tidak tahu lokasi candi Kotes } \\
\text { Belum pernah berkunjung ke candi Kotes }\end{array}$ \\
\hline 3 & SDN Tambakan I & Joko Suseno, S.Pd & Tidak & $\begin{array}{l}\text { Tidak memahami materi candi Kotes } \\
\text { Candi Kotes tidak diajarkan dalam buku pelaja- } \\
\text { ran }\end{array}$ \\
\hline 4 & SDN Kotes I & Hariyati, S.PD,SD & Tidak & $\begin{array}{l}\text { Kesibukan } \\
\text { Tidak memahami materi candi Kotes }\end{array}$ \\
\hline 5 & SDN Sukosewu I & Imam Taptoyani, A.MA & Pernah & $\begin{array}{l}\text { Memanfaatkan candi Kotes sebagai sumber } \\
\text { belajar } \\
\text { Tidak memahami materi candi Kotes (Namun } \\
\text { memanfaatkan jasa penjaga candi Kotes) }\end{array}$ \\
\hline 6 & SDN Sukosewu 4 & Sunarto, S.Pd.SD & Pernah & $\begin{array}{l}\text { Memanfaatkan candi Kotes sebagai sumber } \\
\text { belajar }\end{array}$ \\
\hline
\end{tabular}


Menciptakan pembelajaran yang tidak monoton Tidak memahami materi candi Kotes (Namun memanfaatkan jasa penjaga candi Kotes)

Tabel 4 menunjukkan bahwa intensitas pemanfaatan candi Kotes sebagai sumber belajar masih sangat kurang. Hal tersebut terlihat melalui minimnya intensitas guru yang memanfaatkan candi Kotes sebagai sumber belajar. Dari delapan orang guru yang menjadi informan, hanya dua orang guru saja yang pernah memanfaatkan candi Kotes sebagai sumber belajar sejarah. Mayoritas guru tidak memanfaatkan candi Kotes karena kurang memahami materi tentang sejarah candi Kotes. Hal tersebut mengakibatkan guru kurang memiliki kemampuan untuk memanfaatkan candi Kotes sebagai sumber belajar sejarah.

Disamping kurang memahami materi sejarah candi Kotes, faktor kesibukan juga menjadi salah satu alasan guru untuk tidak memanfaatkan candi Kotes sebagai sumber belajar. Faktor akomodasi juga menjadi salah satu penghambat guru dalam memanfaatkan candi Kotes sebagai sumber belajar.

\section{PEMBAHASAN}

Faktor-faktor yang melatar belakangi pengetahuan seseorang antara lain pendidikan, informasi, sosial budaya dan ekonomi, lingkungan, pengalaman dan usia (Notoadmojo, 2007:35). Pengetahuan guru terhadap sejarah candi Kotes cenderung kurang karena salah satu faktor penting dalam membentuk pengetahuan, yaitu pendidikan. Guru yang menjadi informan hampir semuanya memiliki latar belakang non-sejarah sehingga sangat dimungkinkan guru kurang mendapatkan materi yang cukup mengenai sejarah.

Berbagai faktor yang dapat mempengaruhi usaha pemanfaatan alam sekitar sebagai sumber belajar yaitu (1) kemauan tenaga pengajar (2) kemampuan tenaga pengajar untuk dapat melihat alam sekitar yang dapat digunakan untuk pengajaran (3) kemampuan tenaga pengajar untuk dapat menggunakan sumber alam sekitar dalam pembelajaran (Miarso, 2004:177-178). Pemanfaatan sumber belajar sangat bergantung pada kemampuan guru. Kemampuan guru dalam hal ini adalah kemampuan guru untuk menguasai materi sejarah yaitu berkaitan dengan sejarah candi Kotes. Apabila guru tidak memiliki kemampuan dalam sumber belajar tersebut maka guru cenderung tidak memanfaatkan sumber belajar tersebut.

Dari delapan orang guru yang menjadi informan terdapat enam guru yang belum pernah memanfaatkan candi Kotes sebagai sumber belajar sejarah. mayoritas alasan yang dikemukakan adalah kurang memahami materi sejarah candi Kotes.Guru IPS yang menjadi informan minim akan pengetahuan mengenai sejarah candi Kotes sehingga para guru tersebut kurang mampu dalam menggunakan candi Kotes sebagai sumber belajar. Maka dari itu mereka tidak memanfaatkan candi Kotes sebagai sumber belajar. Adapun dua orang guru yang memanfaatkan candi Kotes sebagai sumber belajar tersebut menggunakan jasa penjaga candi Kotes dalam menjelaskan sejarah candi kotes kepada siswa.

Dalam memanfaatkan candi Kotes sebagai sumber belajar sejarah, peran penjaga candi Kotes rupanya sangat membantu para guru. Guru kurang memiliki pengetahuan mengenai sejarah candi Kotes, namun akhirnya memutuskan untuk memanfaatkan candi Kotes dengan bekerja sama dengan penjaga candi Kotes. Pada pelaksanaan kunjungan, guru hanya mendampingi siswa dan memberikan arahan, sedangkan penjelasan mengenai sejarah candi Kotes diambil alih oleh penjaga candi Kotes.

Faktor informasi juga memegang peranan yang penting dalam membentuk pengetahuan guru. Referensi merupakan salah satu bentuk informasi yang dapat menambah pengetahuan guru 
mengenai candi Kotes. Namun, keberadaan referensi yang membahas mengeni candi Kotes masih sangat minim. Sehingga pengetahuan guru mengenai sejarah candi Kotes tidak dapat berkembang dengan maksimal.

Kehadiran referensi sebagai informasi bagi guru sangat penting guna menunjang pemahaman guru mengenai suatu materi. Secara sederhana referensi dimaknai sebagai informasi yang digunakan sebagai landasan untuk bertindak atau berbuat sesuatu. Referensi dapat berupa jurnal, buku, makalah,skripsi, tesis dan disertasi. Apabila guru tidak memiliki referensi yang berkaitan dengan candi Kotes maka pengetahuan guru mengenai candi Kotes tergolong kurang.

Informasi atau referensi yang diperoleh guru berkaitan dengan candi Kotes akan memberikan dampak meningkatnya pengetahuan guru mengenai candi Kotes. Sedangkan pada kenyataannya referensi atau informasi mengenai candi Kotes masih sangat minim sehingga guru kesulitan dalam mengembangkan pengetahuan mengenai candi Kotes. Maka hal tersebut berdampak terhadap kurangnnya pengetahuan guru mengenai candi Kotes.

\section{PENUTUP}

Pengetahuan guru sangat berpengaruh terhadap pemanfaatan candi Kotes sebagai sumber belajar. Pengetahuan guru mengenai sejarah candi Kotes sangat berkaitan dengan latar belakang pendidikan guru. Mayoritas guru IPS yang mengajar pada sekolah di sekitar candi Kotes tidak memiliki latar belakang pendidikan sejarah sehingga guru tidak memiliki pengetahuan yang cukup mengenai materi sejarah utamanya

\section{DAFTAR RUJUKAN}

Abdullah, M. Y. 2006. Pengantar Studi Etika. Jakarta. PT. Grafindo Persada.

Fred, P and Elington, H. 1993. A Handbook of Education Technology. London: Kogan Page.

Heracki \& Depoter. 2002. Quantum Learning. Bandung: Mizan. sejarah candi Kotes. Hal tersebut berdampak terhadap minimnya intensitas pemanfaatan candi Kotes sebagai sumber belajar. Pengetahuan guru mengenai candi Kotes juga kurang berkembang diakibatkan kurangnya referensi yang dimiliki guru.

Latar belakang pendidikan guru merupakan salah satu faktor penghambat guru dalam memanfataakn candi Kotes sebagai sumber belajar sejarah. Minimnya pemanfaatan candi Kotes sebagai sumber belajar akan berdampak pada kurang tercapainya tujuan pembelajaran sejarah, karena guru kurang memanfaatkan sumber belajar yang ada pada lingkungan sekitar . Kurang tercapainya tujuan pembelajaran sejarah juga akan berpengaruh pada kurang maksimalnya pembelajaran IPS, karena pembelajaran sejarah merupakan bagian dari pelajaran IPS.

Mengingat tidak semua guru memiliki latar belakang sejarah, maka perlu adanya referensi yang cukup mengenai candi Kotes agar guru yang tidak memiliki latar belakang sejarah mampu mengembangkan pengetahuan mereka. Perlu rekomendasi untuk diadakan diklat atau workshop bagi guru guna lebih memanfaatkan sumber sejarah berbasis lingkungan salah satunya adalah candi Kotes. Keberadaan referensi yanng cukup dan pelatihan yang cukup bagi para guru diharapkan mampu mengembangkan pengetahuan guru IPS mengenai materi sejarah khususnya materi yang berkaitan dengan candi Kotes. Dengan pengetahuan yang baik mengenai candi Kotes maka dimungkinkan guru akan memiliki kemampuan untuk memanfaatkan candi Kotes sebagai sumber belajar sehingga pembelajaran sejarah akan lebih maksimal lagi.

Hill, C.P. 1956. Saran-saran Tentang Mengajarkan Sedjarah. Terjemahan Haksan Wirasutina. Jakarta. Perpustakaan Perguruan PPK.

Macbeath, J \& Mortimore, P. 2001. Improving School Effective. Alih Bahasa Nin Bakdi Sumanto. Jakarta: Grasindo. 
Notoadmodjo, S. 1993. Pengantar Pendidikan

dan Ilmu Kesehatan. Jakarta: Rineka Cipta.

Miarso, Y. 2005. Menyemai Benih Teknologi Pendidikan, Jakarta: Kencana.

Morrison, G.R. 2004. Designing Effective Instruction, New York:Jhon Wiley \& Sons Inc.

Sugiyono. 2010. Metode Penelitian Pendidikan: Pendekatan Kuantitatif, Kualitatif, $R \& D$. Bandung: Alfabeta.

Suhanandi, dan Waspodo, T. 2003. Pendidikan IPS. Surabaya: Insan Cendekia. 